\title{
2 Essentiality of the glnA gene in Haloferax mediterranei: gene 3 conversion and transcriptional analysis
}

\author{
4 V. Rodríguez-Herrero ${ }^{1}$ - G. Payá ${ }^{1}$ - V. Bautista ${ }^{1}$ - A. Vegara ${ }^{1} \cdot$ M. Cortés-Molina ${ }^{2} \cdot$ M. Camacho $^{1} \cdot$ J. Esclapez ${ }^{1}$. \\ M. J. Bonete ${ }^{1}$
}

Received: 27 November 2019 / Accepted: 27 March 2020

(c) Springer Japan KK, part of Springer Nature 2020

\begin{abstract}
Glutamine synthetase is an essential enzyme in ammonium assimilation and glutamine biosynthesis. The Haloferax mediterranei genome has two other $g \ln A$-type genes $(g \ln A 2$ and $g \ln A 3)$ in addition to the glutamine synthetase gene $g \ln A$. To determine whether the $g \ln A 2$ and $g \ln A 3$ genes can replace $g \ln A$ in nitrogen metabolism, we generated deletion mutants of $g \ln A$. The $g \ln A$ deletion mutants could not be generated in a medium without glutamine, and thus, $g \ln A$ is an essential gene in $H$. mediterranei. The glnA deletion mutant was achieved by adding $40 \mathrm{mM}$ glutamine to the selective medium. This conditional HM26- $\Delta g \ln A$ mutant was characterised with different approaches in the presence of distinct nitrogen sources and nitrogen starvation. Transcriptomic analysis was performed to compare the expression profiles of the strains HM26- $\Delta \ln A$ and HM26 under different growth conditions. The $g \ln A$ deletion did not affect the expression of $g \ln A 2, g \ln A 3$ and nitrogen assimilation genes under nitrogen starvation. Moreover, the results showed that $g \ln A, g \ln A 2$ and $g \ln A 3$ were not expressed under the same conditions. These results indicated that $g \ln A$ is an essential gene for $H$. mediterranei and, therefore, $g \ln A 2$ and $g \ln A 3$ cannot replace $g \ln A$ in the conditions analysed.
\end{abstract}

Keywords Glutamine synthetase $\cdot$ Polyploidy $\cdot$ Conditional deletion mutant $\cdot$ Ammonium assimilation $\cdot$ Haloarchaea

\section{Introduction}

In bacteria, ammonium can be incorporated into carbon skeletons by ATP-dependent glutamine synthetase (GS) followed by glutamate synthase (GOGAT), allowing the

\section{Communicated by L. Huang.}

V. Rodríguez-Herrero and G. Payá contributed equally to this work.

Electronic supplementary material The online version of this article (https://doi.org/10.1007/s00792-020-01169-x) contains supplementary material, which is available to authorized users.

\section{J. Bonete}

mjbonete@ua.es

1 División de Bioquímica Y Biología Molecular, Departamento de Agroquímica Y Bioquímica, Universidad de Alicante, Carretera de San Vicente del Raspeig s/n, San Vicente del Raspeig, 03690 Alicante, Spain

2 Departamento de Matemática Aplicada, Universidad de Alicante, Carretera de San Vicente del Raspeig s/n, San Vicente del Raspeig, 03690 Alicante, Spain interconversion of glutamate and glutamine in the GSGOGAT pathway (Fisher 1989; Reitzer 2003; Muro-Pastor et al. 2005; Kim et al. 2017) or via glutamate dehydrogenase (GDH) (van Heeswijk et al. 2013). Glutamine synthetase (EC 6.3.1.2) is a key enzyme whose activity is conserved in the Eukarya, Bacteria and Archaea domains. This enzyme plays an essential role in both ammonium assimilation and glutamine biosynthesis, whose product acts as a nitrogen donor for the synthesis of amino acids and nucleotides. GS catalyses glutamine biosynthesis by magnesium- or manganese-dependent biosynthetic reactions from glutamate, ATP and ammonium (Eisenberg et al. 2000). The glutamine synthetase family is divided into three classes, GSI, GSII and GSIII, depending on differences in the molecular mass, sequence and quaternary structure (Woods and Reid 1993). GSI is present in bacteria and archaea (Brown et al. 1994) and is encoded by the $g \ln A$ gene (Domínguez-Martín et al. 2016).

Haloferax mediterranei is a halophilic microorganism that belongs to the Archaea domain and is employed as a model organism to study nitrogen metabolism (Bonete et al. 2008). In H. mediterranei, GS acts in collaboration with

\begin{tabular}{|l|l|l|l|l|}
\hline Journal : Large 792 & Article No : 1169 & Pages : 14 & MS Code : EXT-19-Nov-0215 & Dispatch : 4-4-2020 \\
\hline
\end{tabular}


glutamate synthase (GOGAT, EC 1.4.7.1) in the ammonium assimilative pathway at low ammonium concentrations, while the glutamate dehydrogenase enzyme is active at high ammonium concentrations (Bonete et al. 2008). Currently, it is known that three $g \ln A$-type genes are encoded in the $H$. mediterranei genome: $g \ln A, g \ln A 2$ and $g \ln A 3$. In $H$. mediterranei, $g \ln A 2$ and $g \ln A 3$ have sequence identities of $51.9 \%$ and $49.1 \%$ with $g \ln A$, respectively. In addition, $g \ln A 2$ and $g \ln A 3$ are adjacent in the genome, separated by $1563 \mathrm{bp}$, and show $60.9 \%$ identity with one another (Pedro-Roig et al. 2013). Multiple $g \ln A$ genes have also been found in other bacterial species, such as Mycobacterium tuberculosis, Streptomyces coelicolor, the cyanobacterium Synechocystis and Rhodobacter sphaeroides (Chavez et al. 1999; Li et al. 2010).

$H$. mediterranei is a polyploid microorganism whose genome contains more than 10 copies, similar to other haloarchaea species (Chant et al. 1986; Herrmann and Soppa 2002). The regulation of the genome copy number depends on the growth phase, with fewer copies in the stationary phase and at a low external phosphate concentration than in other conditions (Soppa 2013; Zerulla et al. 2014). Polyploidy has a series of advantages in haloarchaea, of which the following stand out: gene redundancy, lower mutation rate, resistance to radiation and desiccation, long-term survival, gene conversion and DNA as a phosphate storage polymer (Soppa 2011, 2013). One of the evolutionary advantages of polyploidy is gene redundancy. This phenomenon confers a lower mutation ratio, as it allows the repair of the mutated copies of the chromosome from the wild-type copies that are simultaneously present in the cell (Mackwan et al. 2007; Zerulla and Soppa 2014). Repairing mutated copies of the chromosome using wild-type copy information requires intermolecular information to be transferred from one donor molecule to a receptor, and this mechanism is called "gene conversion". In the absence of selection, the genome copy number in polyploid species is equalised by this mechanism, whereas with suitable selection, it results in genomes being compensated in the direction of the essential gene, while genomes lose information from other genes (Soppa 2011; Zerulla and Soppa 2014). This mechanism has already been demonstrated in two archaeal species, H. volcanii (Lange et al. 2011) and Methanococcus maripaludis (Hildenbrand et al. 2011), in which heterozygous cells that simultaneously contain different chromosomes can be selected in different directions depending on the culture medium. This finding indicates that gene redundancy is a possible evolutionary advantage of polyploid microorganisms under unfavourable conditions.

To determine the function of GS proteins in nitrogen assimilation, we generated conditional $g \ln A$ deletion mutants in $H$. mediterranei by optimising the pop-in/pop-out method (Bitan-Banin et al. 2003) in the presence of glutamine (Gln).
Due to polyploidy, the optimal conditions for $g \ln A$ mutant characterisation were analysed in different nitrogen sources. The expression profile of the deletion mutant was carried out by a microarray analysis to examine the adaptation mechanism related to nitrogen metabolism.

\section{Methods}

\section{Strains and growth conditions}

The $H$. mediterranei HM26 (R4 $\Delta$ pyrE2) strain was obtained in a previous work (Pedro-Roig et al. 2013) by the pop-in/ pop-out method (Allers et al. 2004). Cultures (50 ml) were grown in $250 \mathrm{ml}$ Erlenmeyer flasks at $42^{\circ} \mathrm{C}$ with good aeration $(225 \mathrm{rpm})$ and contained a $25 \%(\mathrm{w} / \mathrm{v})$ mixture of inorganic salts (SW) (Rodriguez-Valera et al. 1980). The $\mathrm{pH}$ value was adjusted to 7.3 with $\mathrm{NaOH}$. For characterisation of the deletion mutants in frame with the $g \ln A$ gene (HM26$\Delta g \ln A)$, the growth and stability of the mutant compared to that of the parental strain HM26 in the presence of six different nitrogen sources. The detailed culture medium composition and the performed assays are shown in Table 1. All cultures were inoculated from cells with or without preadaptation into the culture medium with an initial optical density (OD600 nm) of 0.02. Three biological replicates were made for each strain and culture medium. The stability of $g \ln A$ during growth on different culture media was determined by PCR screening, Southern blots and Western blots at the start of the exponential phase, the mid-exponential phase and the stationary phase.

For the microarray experiment, three independent biological replicates were used for each culture medium. Cultures (150 ml) were grown in 1-L Erlenmeyer flasks at $42^{\circ} \mathrm{C}$ with good aeration $(220 \mathrm{rpm})$.

\section{Construction of the $g \ln A$ deletion mutant and screening}

HM26- $\Delta g \ln A$ was constructed by the pop-in/pop-out method, as described previously for $H$. mediterranei (PedroRoig et al. 2013). The genomic organisations of the popout clones and wild type (Supplementary Figure S1) were analysed by PCR screening and Southern blot analysis. PCR was performed with $800 \mathrm{ng}$ of genomic DNA, 1X PCR buffer, $1.5 \mathrm{mM} \mathrm{MgCl}{ }_{2}, 0.16 \mathrm{mM}$ dNTPs, $100 \mathrm{pmol} /$ primer and $1 \mathrm{U}$ BioThermStar DNA polymerase (Genecraft, Germany). The PCR products were confirmed by Sanger sequencing (Stabvida, Caparica, Portugal). For the Southern blot analysis, genomic DNA $(3 \mu \mathrm{g})$ was digested with PdmI (Thermo Scientific, Waltham, Massachusetts, United States). Prehybridisation, hybridisation $\left(65^{\circ} \mathrm{C}\right)$, and chemiluminescent detection were performed as described in the 


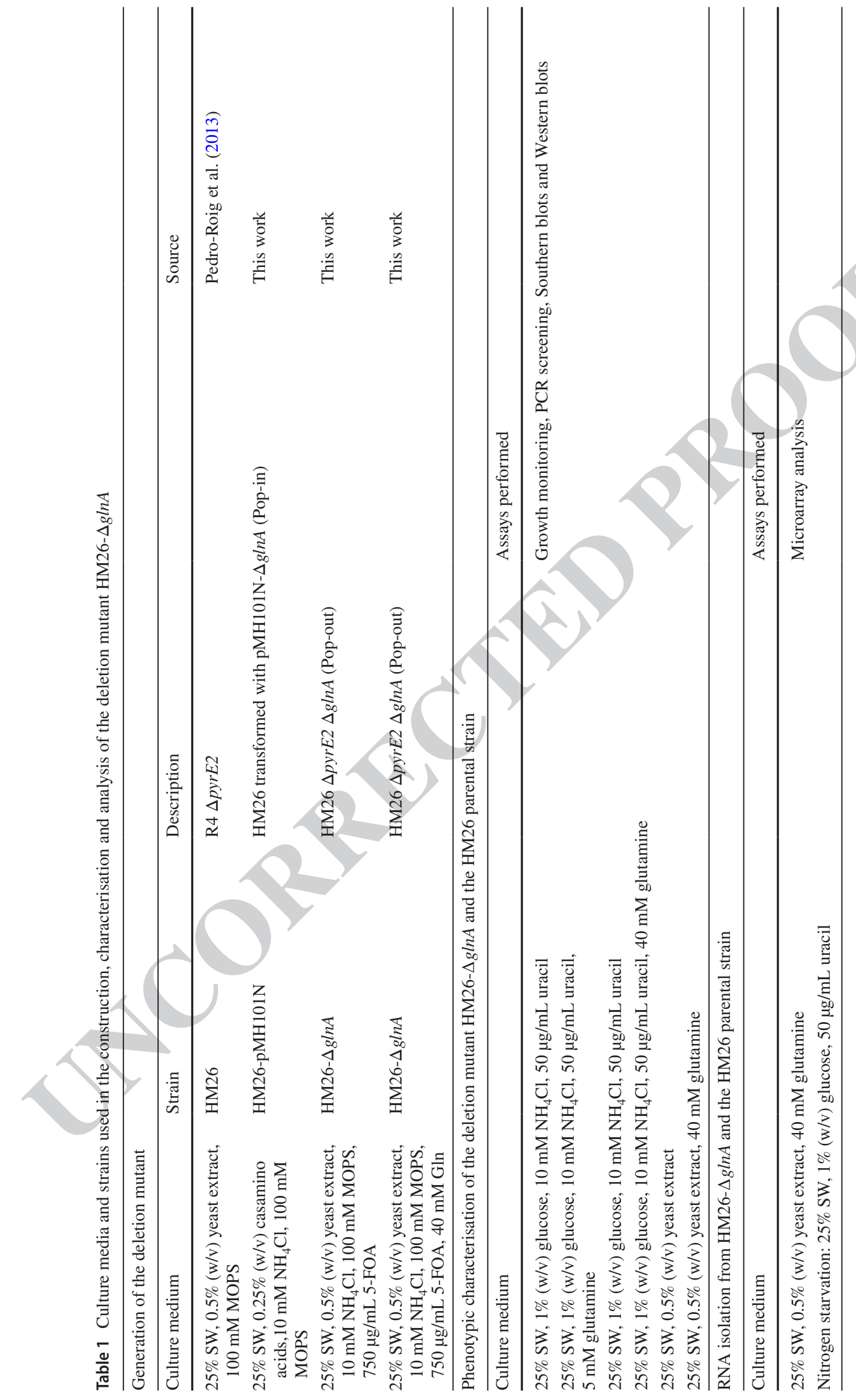


DIG Application Manual for Filter Hybridization (Roche, Basel, Switzerland).

\section{Western blot}

Western blotting was performed as described in the Western Blotting Principles and Methods manual (GE Healthcare) using $20 \mu \mathrm{g}$ of protein extracts, anti-GlnA polyclonal rabbit antibodies (GenScript, New Jersey, United States) as the primary antibody at a concentration of $0.2 \mu \mathrm{g} / \mathrm{mL}$ and a peroxidase-labelled 1:50,000 secondary antibody (Thermo Scientific, Waltham, Massachusetts, United States), which employs luminol as a chemiluminescent substrate (GE Healthcare, Chicago, Illinois, United States).

\section{RNA isolation}

RNA was isolated from the complex medium with $40 \mathrm{mM}$ Gln cultures in the mid-exponential phase of the HM26$\Delta g \ln A$ and HM26 strains. RNA was isolated after nitrogen starvation for $72 \mathrm{~h}$ from the HM26- $\Delta g \ln A$ and HM26 strains (Table 1). Total RNA was isolated with the RNeasy Mini Kit (Qiagen, Hilden, Germany) following product specifications. Quality and quantity were determined by a Bioanalyzer (Agilent, Santa Clara, California, United States) and NanoDrop (Thermo Scientific, Waltham, Massachusetts, United States), respectively. All the samples showed an RNA integrity number (RIN) above 7.

\section{Transcriptome analysis}

Transcriptomic analysis was carried out by following the microarray technique. The probes for microarray analysis were designed based on the $H$. mediterrane $i$ genome and through the use of the software eArray of Agilent Technologies (Esclapez et al. 2015). For each gene, three probes with a length of 60 nucleotides each were designed. RNA labelling, microarray analysis and data processing were performed by the Bioarray, S.L. Company (Alicante, Spain). Gene expression was considered up- or downregulated if the $\log _{2}$ of the fold change was $\geq 2$.0-fold (upregulated) or $\leq-2.0$-fold (downregulated) and statistically significant ( $p$-value $<0.05$ ). The data were analysed using the Limma package from Bioconductor. For the HM26 and HM26$\Delta g \ln A$ transcriptome analysis, $\mathrm{Cx}$ was taken as the reference. The microarray data can be accessed in the Gene Expression Omnibus (GEO) database (accession number: GSE135303).

The functional analysis was performed using the following databases: KEGG (www.genome.jp/kegg), NCBI (www. ncbi.nlm.nih.gov), and BRENDA (www.brenda-enzym es.org). Genes were classified according to the metabolic pathway with which they were related in several categories (Supplementary Table S1).

\section{Microarray data validation}

The microarray results were validated by quantitative RTPCR (RT-qPCR). The RNA samples were treated with TURBO DNase (Applied Biosystems, Foster City, California, United States). Subsequently, for cDNA synthesis, RNA $(0.5-0.6 \mu \mathrm{g})$ and M-MuLV Reverse Transcriptase (Thermo Scientific, Waltham, Massachusetts, United States) were used. Negative controls were performed without enzyme and RNA. Oligonucleotides were designed using Primer Express 2.0 software (Applied Biosystems, Foster City, California, United States) (Table 2), and 16S RNA (NC 017941) was used as an endogenous control. RT-qPCR was carried out in a StepOnePlus Real-Time PCR System (Applied Biosystems). Amplification reactions were performed using $12.5 \mu \mathrm{L}$ of $\mathrm{SYBR}^{\circledR}$ Green $2 \times \mathrm{PCR}$ Master Mix (Applied Biosystems) and $2.5 \mathrm{pmol} / \mu \mathrm{L}$ of each primer. All RT-qPCR reactions were performed in triplicate.

The RT-qPCR programme consisted of a fusion cycle of $10 \mathrm{~min}$ at $95{ }^{\circ} \mathrm{C}$, followed by 40 cycles of $15 \mathrm{~s}$ at $95^{\circ} \mathrm{C}$, $1 \mathrm{~min}$ at $55^{\circ} \mathrm{C}$ and $30 \mathrm{~s}$ at $72{ }^{\circ} \mathrm{C}$. Subsequently, the melting curve was recorded between 60 and $95^{\circ} \mathrm{C}$.

\section{Results and discussion}

\section{Construction of the $g \ln A$ deletion mutant in $H$.} mediterranei

HM26- $\Delta g \ln A$ was constructed by the pop-in/pop-out method (Bitan-Banin et al. 2003). Genomic organisation (Figure S1) was confirmed by PCR screening and Southern blot analysis of the pop-out clones. More than one hundred pop-out clones analysed by PCR screening and Southern blot analysis revealed that all the clones presented the parental HM26 genotype (Fig. 1), indicating that the $g \ln A$ gene is essential

Table 2 Summary of the primers used in RT-qPCR

\begin{tabular}{lll}
\hline Primer name & Sequence $5^{\prime} \rightarrow 3^{\prime}$ & $\begin{array}{l}\text { Ampli- } \\
\text { con size } \\
(\mathrm{bp})\end{array}$ \\
\hline rRNA 16S Forward & CACAAGAGTGCGGTGATACGT & 66 \\
rRNA 16S Reverse & CCTCACTCGGTTGCTTTGAC & \\
glnA2 Forward & GGTCGACCCGTGTGACCTC & 51 \\
glnA2 Reverse & TTGATTCCTTTGCGGTCC & \\
gdh Forward & AAGCAGTCCACGAGGTGACC & 60 \\
gdh Reverse & TGTAGACCGAAACAGACC CGT & \\
nasA Forward & GACGAGTGTATGCCTG & 56 \\
nasA Reverse & TTCAACTGGTGGACGTCGTC & \\
nasD Forward & TCGCTGGCTCAGAGACAATG & 50 \\
nasD Reverse & GACCCAAGGTGAACGTGACC & \\
\hline
\end{tabular}

23

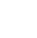

8

.

.

.




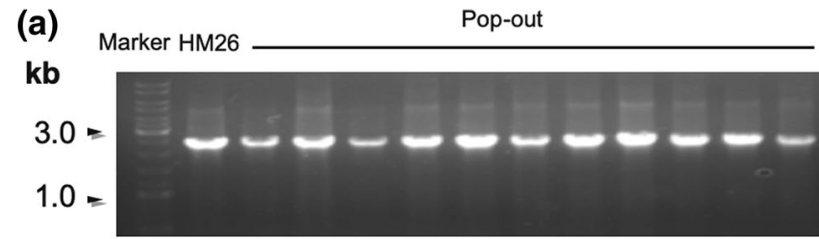

(b)

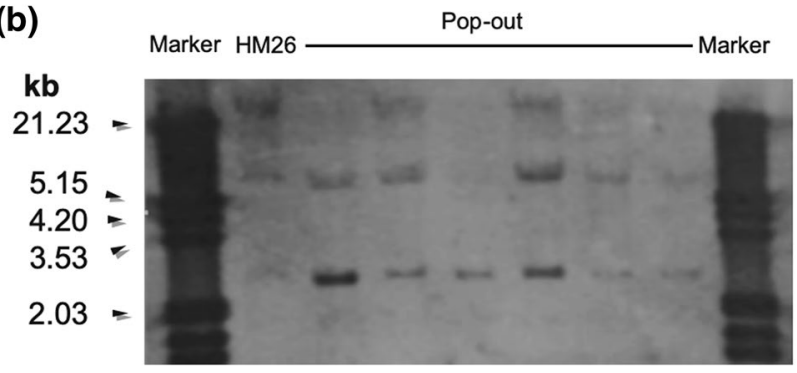

Fig. 1 Generation of the $g \ln A$ gene deletion mutant in complex medium with 5-FOA. a PCR screening of pop-out clones (1000 bp) and HM26 (2300 bp) b Southern blot analysis using the PdmI restriction enzyme of pop-out clones and HM26. The $g \ln A$ deletion mutant should have one band of $4.58 \mathrm{~kb}$, and the parental HM26 strain should have two bands of 5.94 and $2.34 \mathrm{~kb}$ for $H$. mediterranei, despite genetic redundancy. Other studies in species such as M. tuberculosis and M. maripaludis have corroborated this conclusion (Cohen-Kupiec et al. 1999; Harth et al. 2005). This enzyme plays a fundamental role in ammonium assimilation and glutamine synthesis (Bonete et al. 2008). Therefore, the product of the glutamine synthetase reaction could be essential as a nitrogen donor for nitrogen metabolism through glutamine and/or for protein synthesis (Cohen-Kupiec et al. 1999).

Essential genes cannot be deleted, but the functions of their gene products can be studied in vivo when conditional deletion is possible. Therefore, conditional deletion mutants of the $g \ln A$ gene were successfully generated using an excess of Gln $(40 \mathrm{mM})$ in complex medium with 5-FOA. A similar modification of the pop-in/pop-out method has already been made to generate auxotrophic amino acid mutants (Allers et al. 2004; Jantzer et al. 2011). The pop-out clones (HM26$\Delta g \ln A)$ grown under these conditions were successfully confirmed by PCR screening and Southern blots (Fig. 2). These results confirmed that the pop-out mutants (HM26- $\Delta \ln A$ ) were unable to grow in the absence of glutamine and that GS is an essential enzyme in $H$. mediterranei. These results indicated that the $g \ln A 2$ and $g \ln A 3$ genes do not encode functional GS or are not expressed under the same conditions as $g \ln A$, in contrast to the results of Reyes and Florencio (1994), where putative GS compensates for the activity of GS, allowing the generation of $g \ln A$ deletion mutants. Another hypothesis is that $\mathrm{G} \ln \mathrm{A} 2$ and $\mathrm{G} \ln \mathrm{A} 3$ are regulatory subunits of GlnA and form heterooligomeric structures, as
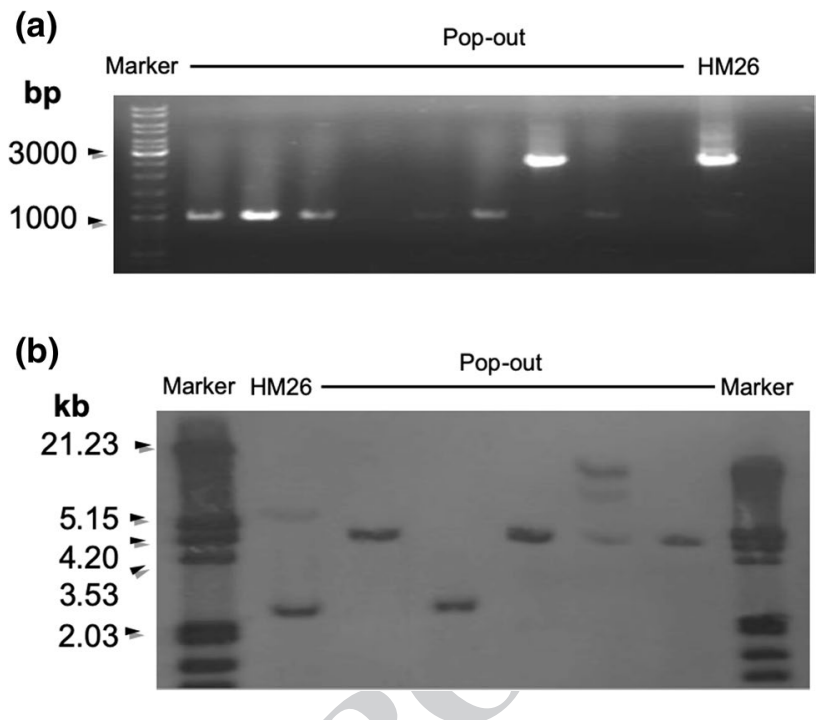

Fig. 2 Generation of the $\ln A$ gene deletion mutant in complex medium with 5-FOA and $40 \mathrm{mM}$ Gln. a PCR screening of pop-out clones (1000 bp) and HM26 (2300 bp) b Southern blot analysis using the $P d m \mathrm{I}$ restriction enzyme of pop-out clones and HM26. The $g \ln A$ deletion mutant presented one band of $4.58 \mathrm{~kb}$, and the parental HM26 genotype presented two bands of 5.94 and $2.34 \mathrm{~kb}$

is the case for glutamate dehydrogenases (GdhA and GdhB) from Thermus thermophilus (Tomita et al. 2010), where GdhA and GdhB act as regulatory and catalytic subunits, respectively, and GdhA stimulates the allosteric activation of GdhB by hydrophobic amino acids. Enzymes involved in other pathways, such as isocitrate dehydrogenase (IDH) from Saccharomyces cerevisiae (Cupp and McAlister-Henn 1993), where IDH1 acts as a catalytic subunit and IDH2 as a regulatory subunit, were shown to form a heterooctameric $\alpha 4 \beta 4$-like structure, in which IDH2 is an allosteric activator of IDH1. Multiple $g \ln A$-type genes have been found in bacteria (Chavez et al. 1999; Li et al. 2010), and for the five $g \ln A$-type genes from $R$. sphaeroides, only $g \ln A 1$ appears to be functional in vivo, as it was the only gene capable of restoring the ammonium assimilation function in the $g \ln A$ Escherichia coli null strain YMC11 (Li et al. 2010). Interaction studies have been performed of the three recombinant proteins $(\mathrm{Gln} A, \mathrm{G} \ln \mathrm{A} 2$ and $\mathrm{G} \ln \mathrm{A} 3)$, and the results showed that the presence of $\mathrm{G} \ln \mathrm{A} 2$ and $\mathrm{G} \ln \mathrm{A} 3$ in the $\mathrm{Gln} \mathrm{A}$ reaction medium increased the catalytic activity of GlnA (Vegara, 2017). However, these data are not conclusive, and it remains unknown whether $H$. mediterranei $g \ln A 2$ and $g \ln A 3$ are involved in GS regulation.

Moreover, these results suggested that $H$. mediterranei can transport glutamine directly into the cytoplasm. Unlike that in M. maripaludis, GS is also an essential enzyme, and even supplementation of the culture medium with glutamine did not result in growth. Therefore, M. maripaludis is unable to transport Gln from the medium (Cohen-Kupiec

\begin{tabular}{|l|l|l|l|l|}
\hline Journal : Large 792 & Article No : 1169 & Pages : 14 & MS Code : EXT-19-Nov-0215 & Dispatch : 4-4-2020 \\
\hline
\end{tabular}


et al. 1999). Glutamine transport could be carried out by unspecified amino acid transporters or by specific glutamine transporters in $H$. mediterranei. The presence of an $\mathrm{ABC}$ type glutamine/glutamate/polar amino acid transport system (HFX_2439, HFX_2440, HFX_2441) in the genome of $H$. mediterranei and HM26 growth in the presence of glutamine as a unique nitrogen source (data not shown) support this hypothesis.

\section{Characterisation of HM26- $\Delta g \ln A$ at different glutamine concentrations}

Strains HM26- $\Delta g \ln A$ and HM26 were grown in triplicate in different culture media in the presence or absence of glutamine (Table 1). PCR screening, Southern blots and Western blots were performed to verify whether $g \ln A$ deletion remained stable throughout growth in all the culture media. These analyses were carried out in three stages of growth: the start of the exponential phase, the mid-exponential phase and the stationary phase.
HM26- $\Delta \ln \ln$ and HM26 grown in defined medium containing $10 \mathrm{mM} \mathrm{NH}_{4} \mathrm{Cl}$ did not present any significant growth differences in the presence or absence of $5 \mathrm{mM}$ Gln (Fig. 3a).

If HM26- $\Delta g \ln A$ are Gln auxotrophic mutants, they would not be expected to grow in liquid medium in the absence of Gln, as in other species (Reyes and Florencio 1994; Li et al.2010) and other auxotrophic mutants of $H$. volcanii (Jantzer et al. 2011). However, HM26- $\Delta$ gln $A$ could grow in liquid (Figs. 3a, 4a and 5a) and solid medium without Gln (data not shown). Thus, H. mediterranei is a polyploid organism (Soppa 2013), and these results suggested that the obtained HM26- $\Delta \ln A$ was not a complete deletion mutant, probably because some $\operatorname{gln} A$ copies remained in certain chromosomes of this microorganism that were not detectable by PCR screening and Southern blots (Fig. 2). One of the evolutionary advantages of polyploidy is gene redundancy, which has already been demonstrated in archaeal species (Hildenbrand et al. 2011; Lange et al. 2011). In the absence of selection, the number of copies of the genome in polyploid species is balanced by a gene conversion mechanism,
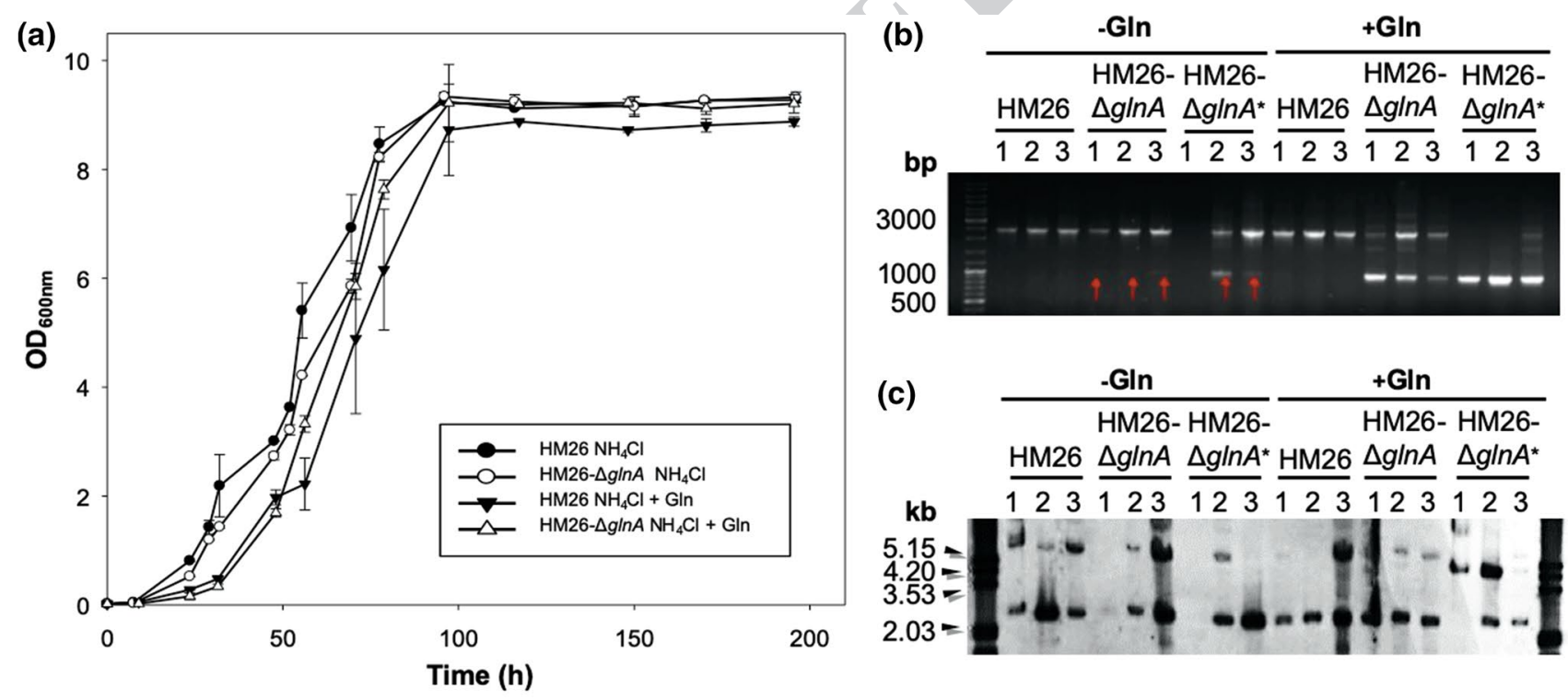

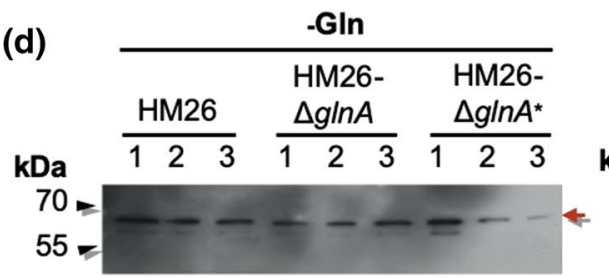

Fig. 3 Characterisation of HM26- $\Delta g \ln A$ versus HM26 grown in defined medium containing $10 \mathrm{mM} \mathrm{NH}_{4} \mathrm{Cl}$ with/without $5 \mathrm{mM} \mathrm{Gln}$. Growth phases: start of the exponential phase (1), the mid-exponential phase (2) and the stationary phase (3). $\Delta g \ln A$ : inoculated from a preadapted inoculum. $\Delta g \ln A^{*}$ : inoculated directly with the stored mutant at $-80{ }^{\circ} \mathrm{C}$. a Growth curves. b PCR screening. The paren-

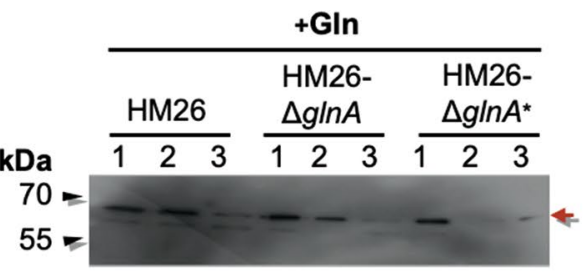

tal HM26 strain has a band of $2300 \mathrm{bp}$. The mutant has a band of $1000 \mathrm{bp}$. The red arrows indicate the band corresponding to $1000 \mathrm{bp}$. c Southern blot. The parental HM26 strain has two bands of 5.94 and $2.34 \mathrm{~kb}$. The mutant has a band of $4.58 \mathrm{~kb}$. d Western blot. The red arrows indicate the band corresponding to the GS protein

\begin{tabular}{|l|l|l|l|l|}
\hline Journal : Large 792 & Article No : 1169 & Pages : 14 & MS Code : EXT-19-Nov-0215 & Dispatch : 4-4-2020 \\
\hline
\end{tabular}



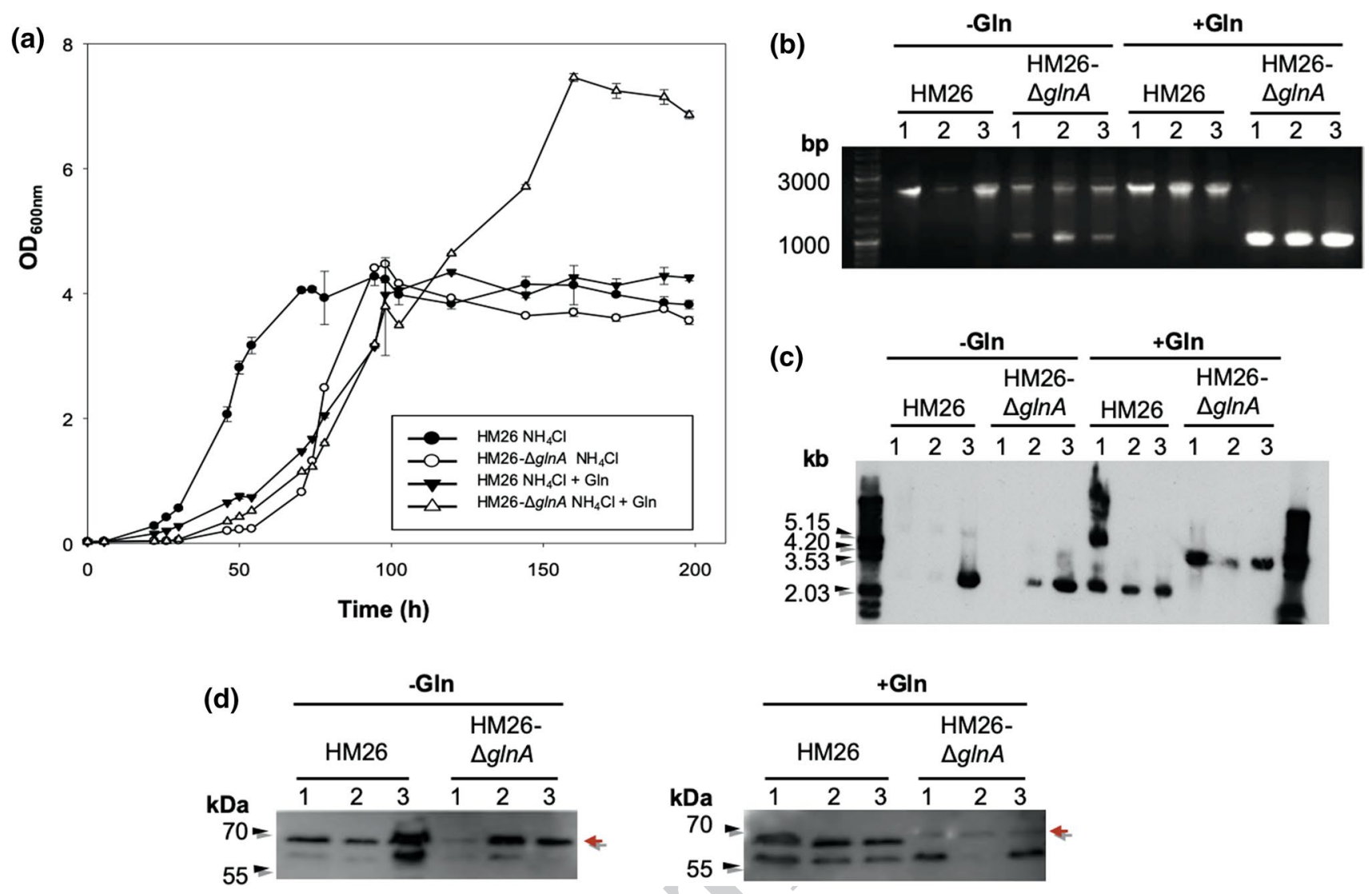

Fig. 4 Characterisation of HM26- $\Delta g \ln A$ versus HM26 grown in defined medium containing $10 \mathrm{mM} \mathrm{NH}_{4} \mathrm{Cl}$ with/without $40 \mathrm{mM} \mathrm{Gln}$. Growth phases: start of the exponential phase (1), the mid-exponential phase (2) and the stationary phase (3). a Growth curves. b PCR screening. The parental HM26 strain has band of $2300 \mathrm{bp}$. The

mutant has a band of 1000 bp. c Southern blot. The parental HM26 strain has two bands of 5.94 and $2.34 \mathrm{~kb}$. The mutant has a band of $4.58 \mathrm{~kb}$. $\mathbf{d}$ Western blot. The red arrows indicate the band corresponding to the GS protein

whereas in the presence of suitable selection, compensation of the genomes in the direction of the appropriate essential gene occurs (Soppa 2011; Zerulla and Soppa 2014). Heterozygous cells simultaneously containing different genomes can be selected in different directions depending on the culture medium, which indicates that gene redundancy is a possible evolutionary advantage of polyploid microorganisms in unfavourable conditions (Lange et al. 2011; Hildenbrand et al. 2011). As the used medium lacked Gln, this condition would favour an increase in the number of initially undetectable $g \ln A$-presenting chromosomes; therefore, in the absence of Gln, the wild-type genotype returned. When Gln was absent, HM26- $\Delta g \ln A$ presented a heterozygous genotype from the starting point of growth. However, in the presence of $5 \mathrm{mM}$ glutamine, HM26- $\Delta g \ln A$ with no adaptation (pop-out mutants were inoculated directly into the culture medium) presented a heterozygous genotype only in the stationary phase (Fig. 3b, c). Western blotting (Fig. 3d) showed GS expression in both the presence and absence of $5 \mathrm{mM}$ glutamine (HM26- $\Delta g \ln A$ and HM26), which confirmed that the Gln concentration used was inadequate for maintaining the $g \ln A$ deletion and that gene conversion would occur at the beginning of the exponential phase if glutamine was absent.

\section{Glutamine effect on the gene conversion process of the conditional deletion mutant}

HM26- $\Delta g \ln A$ was grown in defined medium containing $10 \mathrm{mM} \mathrm{NH}_{4} \mathrm{Cl}$ with/without $40 \mathrm{mM}$ glutamine. The culture with HM26- $\Delta g \ln A$ in the presence of Gln reached the stationary phase at a higher OD600 $\mathrm{nm}$ than the other cultures (Fig. 4a). This finding could be because HM26- $\Delta g \ln A$ in the absence of Gln presents the wild-type genotype and reaches the stationary phase at OD600 nm, similar to HM26, whereas for HM26- $\Delta g \ln A$ in the presence of Gln $40 \mathrm{mM}$, the gene conversion occurs in the opposite direction, presenting predominantly chromosomes with the $g \ln A$ deletion (Fig. 4b, c), behaving in a different way than the parental strain. However, in the absence of Gln, HM26- $\Delta g \ln A$ presented a longer lag phase than HM26 (the time in which gene conversion would occur). PCR screening and Southern blots (Fig. 4b,
348 349 350 351 352 353 354 355 356 357 358 359 360 361

\begin{tabular}{|l|l|l|l|l|}
\hline Journal : Large 792 & Article No : 1169 & Pages : 14 & MS Code : EXT-19-Nov-0215 & Dispatch : 4-4-2020 \\
\hline
\end{tabular}



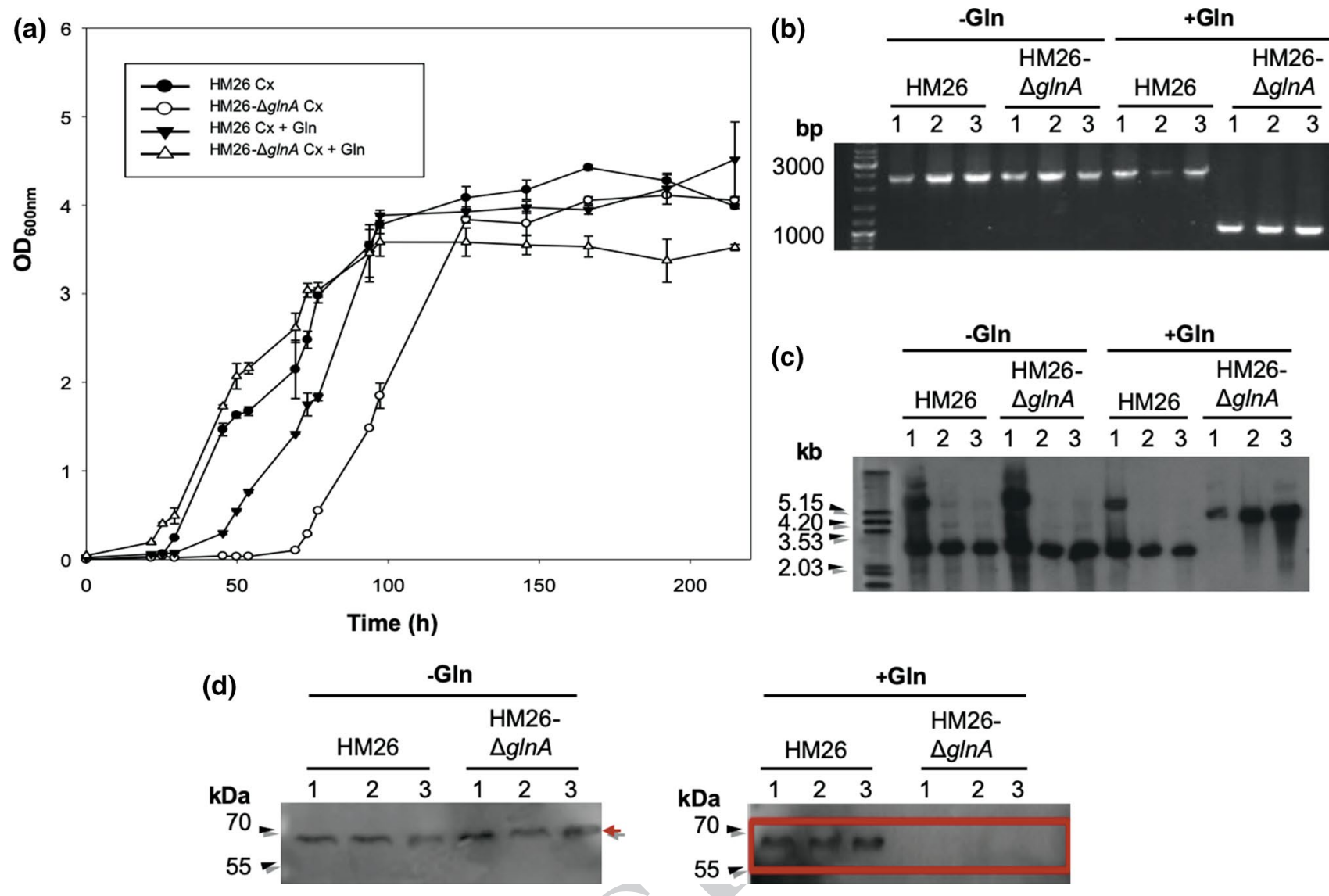

Fig. 5 Characterisation of HM26- $\Delta \mathrm{g} \ln A$ versus HM26 grown in complex medium $(\mathrm{Cx})$ with/without $40 \mathrm{mM}$ Gln. Growth phases: start of the exponential phase (1), the mid-exponential phase (2) and the stationary phase (3). a Growth curves. b PCR screening. The parental HM26 strain has a band of $2300 \mathrm{bp}$. The mutant has a band of 1000 bp. c Southern blot. The parental HM26 strain has two bands of

c) revealed the heterozygous genotype in HM26- $\Delta \ln A$, regardless of the growth stage in the absence of Gln (as in Fig. 3b). In contrast to the observed results of HM26- $\Delta g \ln A$ in the presence of $5 \mathrm{mM} \mathrm{Gln}$ (Fig. 3b), where the heterozygous genotype appeared in the middle of the exponential phase and in the stationary phase, after the concentration of Gln was increased to $40 \mathrm{mM}$, the heterozygous genotype was not observed in any growth phase, and only the deleted version was observed in all phases (Fig. 4b, c).

To obtain optimal conditions for the characterisation of the $\operatorname{gln} A$ mutant, we analysed growth in the complex medium both with/without $40 \mathrm{mM}$ Gln. Under these conditions, the obtained growth curves (Fig. 5a) showed that HM26- $\Delta \ln A$ in the absence of Gln presented a longer lag phase than that in the other cultures, as previously observed. Therefore, it is likely that gene conversion occurs during this time. This fact would explain the longer time taken to reach the exponential phase and the larger number of $g \ln A$ copies observed at the beginning of the exponential phase than
5.94 and $2.34 \mathrm{~kb}$. The mutant has a band of $4.58 \mathrm{~kb}$. d Western blot. The red arrows indicate the band corresponding to the GS protein in the absence of glutamine. The red box indicates the size at which the band corresponding to the GS protein should appear in the absence of glutamine

those in the other conditions. HM26- $\Delta g \ln A$ in $40 \mathrm{mM}$ Gln presented similar growth to HM26 in the absence of Gln, as no gene conversion occurred in this condition. Moreover, the $g \ln A$ deleted version was confirmed in all the growth phases in HM26- $\Delta g \ln A$ and in the presence of $40 \mathrm{mM}$ Gln (Fig. 5b, c) by Western blots (Fig. 5d), where signals of glutamine synthetase expression were detected only in the absence of glutamine.

HM26- $\Delta \ln A$ presented a heterozygous genotype in all growth phases when grown in defined medium with $10 \mathrm{mM}$ $\mathrm{NH}_{4} \mathrm{Cl}$ in the absence of Gln, whereas HM26- $\Delta g \ln A$ presented a parental genotype in all growth phases in complex medium in the absence of Gln. These results indicate that the lack of Gln acts as a selective factor in the initial growth stages by exerting selective pressure in the complex medium. Moreover, it was confirmed that $5 \mathrm{mM}$ Gln could not maintain the mutation, which favoured the increase in the number of copies of the chromosomes with the $g \ln A$ original version during growth. In the presence of $40 \mathrm{mM}$

\begin{tabular}{|l|l|l|l|l|}
\hline Journal : Large 792 & Article No : 1169 & Pages : 14 & MS Code : EXT-19-Nov-0215 & Dispatch : 4-4-2020 \\
\hline
\end{tabular}


Gln, gene conversion occurred in the opposite direction and predominantly presented chromosomes with the $\operatorname{gn} A$ deleted version. According to Soppa (2013), this process occurred in the exponential phase, in contrast to our results, which revealed that it occurred at the beginning of the exponential phase. This evidence confirmed that adding $40 \mathrm{mM}$ Gln to the culture media could be adequate for HM26- $\Delta g \ln A$ selection, as a larger number of copies of the $g \ln A$ deleted version was presented. However, in the defined medium with $40 \mathrm{mM}$ Gln, HM26- $\Delta \ln \ln$ showed GS expression, and the intensity was lower than that in the absence of Gln. Notably, in the complex medium with $40 \mathrm{mM}$ Gln, no GS expression was observed in any growth phase. These findings indicated that conditional HM26- $\Delta \operatorname{gn} A$ mutants behave similarly to homozygous $g \ln A$ deletion mutants as they do not express GS in all the growth stages for this condition. Therefore, the complex medium supplemented with $40 \mathrm{mM}$ Gln would be the appropriate condition for HM26- $\Delta g \ln A$ selection, where no copies of the $g \ln A$ version were detected by the different approaches performed.

\section{Microarray analysis}

The effect of GS deletion on global gene expression was studied by microarray analysis. The genotype was validated by PCR (Figure S2) (Fig. 6).
The $\mathrm{Cx}(\Delta g \ln A)-\mathrm{Cx}$ contrast showed only 52 genes with differential expression, including 49 downregulated genes (Table 3). Most of these genes were related to genetic information processing (Table S2), whereas some were related to nitrogen metabolism (Table S3). Many of the genes related to nitrogen metabolism are involved in the 2-oxocarboxilic acid pathway (HFX_2689, HFX_6032, HFX_6040, and HFX_6359). The change in the expression of these genes could lead to pyruvate and oxocarboxylic acid accumulation. Cells may use these acids as precursors for butanoate and propanoate intermediate biosynthetic pathways and may lead to the synthesis of polyhydroxyalkanoate for energy storage. Polyhydroxyalkanoate accumulation is one of the most common mechanisms by which haloarchaea adapt to hypersaline environments. Changeable carbon sources also serve as carbon storage resources and energy in many archaea under excess carbon conditions (Fernandez et al. 1986). Poly 3-hydroxybutyrate-co-3-hydroxyvalerate is synthesised from carbohydrates as a carbon source in several halophilic strains (Van-Thuoc et al. 2012). In $H$. mediterranei, several pathways leading to propionyl-CoA, an important precursor of 3-hydroxyvalerate for poly3hydroxybutyrate-co-3-hydroxyvalerate synthesis, have been described (Han et al. 2013). As expected, the genes related to nitrogen assimilation metabolism did not show any differences in their expression levels because these genes are not expressed under excess nitrogen and carbon conditions
Fig. 6 Glutamine acts as a selective pressure in the gene conversion process of HM26$\Delta g \ln A$
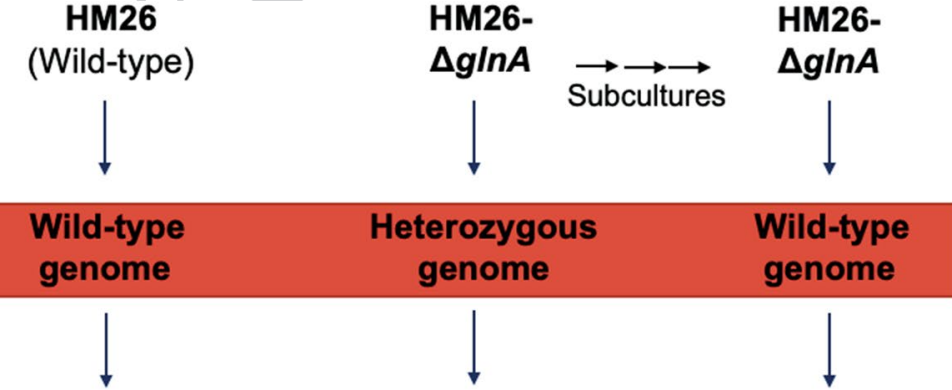

\begin{tabular}{|ccc|}
\hline Wild-type & $\begin{array}{c}\text { Deletion mutant } \\
\text { genome }\end{array}$ & $\begin{array}{c}\text { Heterozygous } \\
\text { genome }\end{array}$ \\
\hline
\end{tabular}

Table 3 Number of genes upregulated and downregulated in each comparison analysed

\begin{tabular}{|c|c|c|c|c|}
\hline Gene expression conditions & Comparison & Total genes & $\begin{array}{l}\text { Upregu- } \\
\text { lated } \\
\text { genes }\end{array}$ & $\begin{array}{l}\text { Down- } \\
\text { regulated } \\
\text { genes }\end{array}$ \\
\hline $\begin{array}{l}\text { HM26- } \Delta g \ln A \text { in complex medium with } 40 \mathrm{mM} \\
\text { Gln }(\mathrm{Cx}(\Delta g \ln A)) \\
\text { HM26 in complex medium with } 40 \mathrm{mM}(\mathrm{Cx})\end{array}$ & $\mathrm{Cx}(\Delta g \ln A)-\mathrm{Cx}$ & 52 & 3 & 49 \\
\hline $\begin{array}{l}\text { HM26 in nitrogen starvation (Nsta) } \\
\text { HM26 in complex medium with } 40 \mathrm{mM} \mathrm{(Cx)}\end{array}$ & Nsta-Cx & 432 & 220 & 212 \\
\hline $\begin{array}{l}\text { HM26- } \Delta g \ln A \text { in nitrogen starvation }(\mathrm{Nsta}(\Delta g \ln A)) \\
\text { HM26 in complex medium with } 40 \mathrm{mM}(\mathrm{Cx})\end{array}$ & $\operatorname{Nsta}(\Delta g \ln A)-\mathrm{Cx}$ & 446 & 207 & 239 \\
\hline
\end{tabular}

$40 \mathrm{mM}$ glutamine

without glutamine

\begin{tabular}{|l|l|l|l|l|}
\hline Journal : Large 792 & Article No : 1169 & Pages : 14 & MS Code : EXT-19-Nov-0215 & Dispatch : 4-4-2020 \\
\hline
\end{tabular}


(Fig. 7). Surprisingly, two of the three genes upregulated in this comparison (HFX_2207 shows a $\log _{2}$ FC $2.03 \pm 0.11$ and HFX_2209 shows a $\log _{2}$ FC $2.90 \pm 0.08$ ) encoded dimethylsulfoxide reductase, which accepts electrons under anaerobic conditions, where malate is used as a carbon source (Kappler et al. 2002). Likewise, when pyruvate replaces malate as a carbon source, dimethylsulfoxide reductase activity is induced in aerobically grown cells (Kappler et al. 2002). Furthermore, the 3-hydroxypropionate pathway allows haloarchaea to use $\mathrm{HCO}_{3}{ }^{-}$and acetyl-CoA for carbon storage and may assimilate the 3-hydroxypropionate generated from marine environments (Berg et al. 2010; Todd et al. 2010). Hence, the activation of the $d m s$ gene could contribute to the generation of dimethylsulfoniopropionate, which could be used as a precursor of 3-hydroxypropionate.
Nitrogen starvation induces differences in the transcriptional profiles of many genes, as described in Esclapez et al. (2015). This finding was also observed in the Nsta$\mathrm{Cx}$ comparison, where 72-h nitrogen starvation resulted in the transcriptional changes in 432 genes (Table 3). Most of these genes were related to both the nitrogen metabolism and transport systems (Tables S3 and S4).

Most transporters showing increased expression are related to $\mathrm{ABC}$ transporters. Two high-affinity ammonium transporters, amt (HFX_0093 and HFX_0095), are overexpressed. Regarding nitrogen metabolism, 30 exclusively upregulated genes related to phenylalanine, tyrosine and tryptophan biosynthesis (HFX_2463, HFX_2464, HFX_2465, HFX_0746, HFX_0747, HFX_0748, HFX_0749, HFX_2462), arginine biosynthesis (HFX_0041,

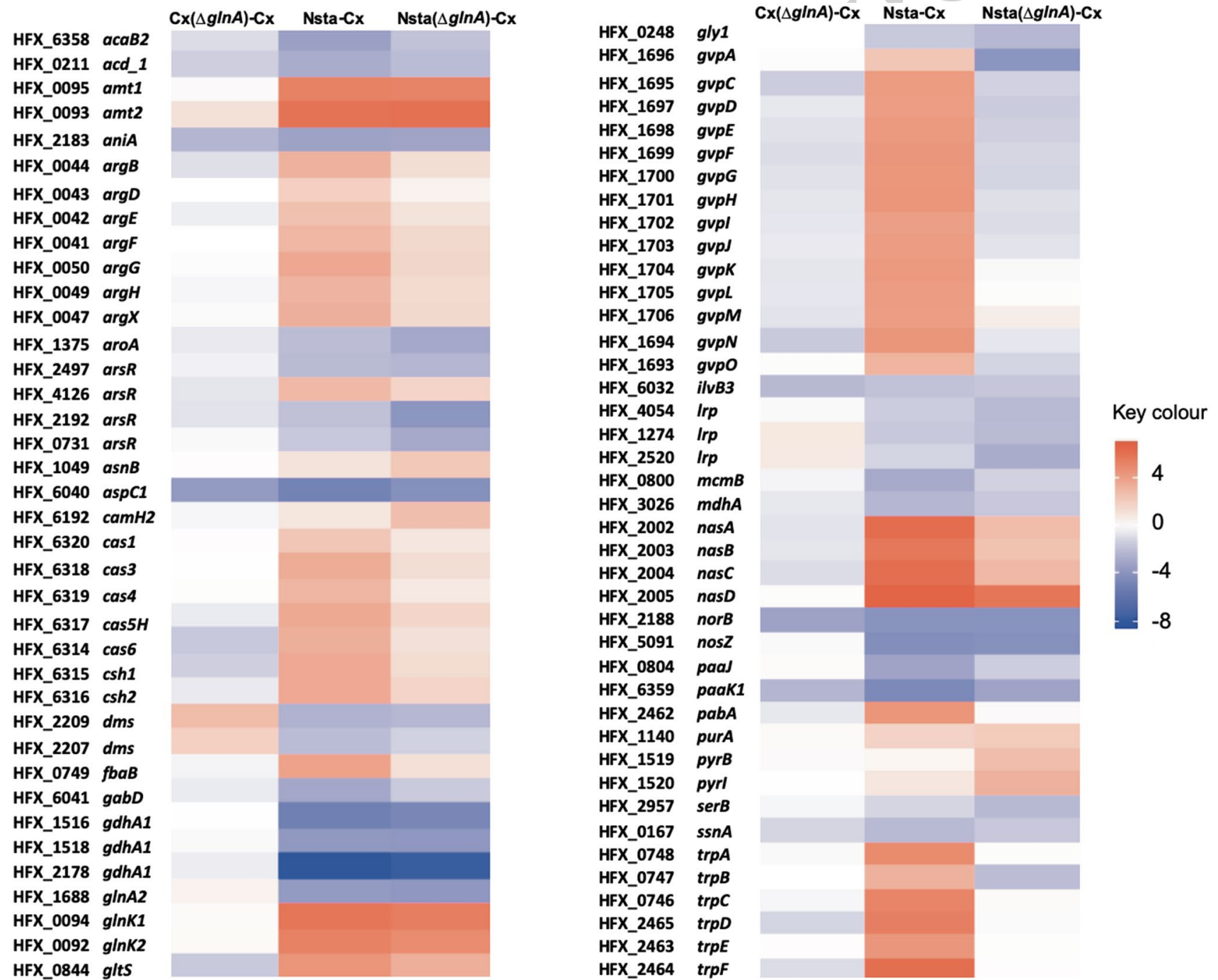

Fig. 7 Heat map. Analysis of genes with differential expression in the three comparison groups: $\operatorname{Cx}(\Delta g \ln A)-\mathrm{Cx}$, Nsta-Cx and $\operatorname{Nsta}(\Delta g \ln A)-\mathrm{Cx}$. The most relevant genes, such as genes involved in the nitrogen assimilative pathway, CRISPR system, vesicle gas metabolism, and transcriptional regulation, are represented in this heat map. Red colour indicates high expression levels, and blue indicates low expression levels

\begin{tabular}{|l|l|l|l|l|}
\hline Journal : Large 792 & Article No : 1169 & Pages : 14 & MS Code : EXT-19-Nov-0215 & Dispatch : 4-4-2020 \\
\hline
\end{tabular}


HFX_0042，HFX_0043，HFX_0044，HFX_0047, HFX_0049, HFX-0050) and glutamine biosynthesis (HFX_0245) were detected. In this comparison, 10 exclusively downregulated genes were found to be involved in cysteine and methionine degradation (HFX_0167, HFX_3026), lysine degradation (HFX_0211), glutamate metabolism (HFX_6041), and branched amino acid degradation (HFX_0800, HFX_0804, HFX_6358). The expression of some of the genes involved in amino acid biosynthesis increases in the absence of a nitrogen source, which could be due to the degradation of other amino acids acting as donors of amino groups. The genes involved in the nitrate assimilation pathway, nas ABCD (HFX_2002, HFX_2003, HFX_2004, and HFX_2005), were overexpressed under nitrogen starvation. Under this condition, glnA (HFX_0245) and gltS (HFX_0844) expression was also overexpressed in the parental strain. These results agree with previous studies, which showed that the GS/GOGAT pathway (encoded by the glnA and gltS genes) was active under limiting-nitrogen conditions (Pire et al. 2014; Esclapez et al. 2015). Under this condition, $g \ln A 2$ gene expression (HFX_1688) was downregulated. It was expected that this gene, similar to $g \ln A$, would be upregulated because it also encodes a GS protein.

Other genes related to nitrogen metabolism, such as genes that encode nitrogen regulatory PII proteins (HFX_0092 and HFX_0094), were upregulated. PII proteins were previously described as activating GS by direct protein-protein interactions in H. mediterranei (Pedro-Roig et al. 2011).

The $g d h$ genes (HFX_1516, HFX_1518, HFX_2178) were downregulated under nitrogen starvation conditions (Fig. 7). Glutamate dehydrogenase (GDH) is active at high ammonium concentrations (Pire et al. 2014). Furthermore, the genes related to denitrification (HFX_2183, HFX_2188, HFX_5091) were downregulated. In this comparison, and exclusively upregulated genes related to gas vesicle metabolism (HFX_1693, HFX_1694, HFX_1695, HFX_1696, HFX_1697, HFX_1698, HFX_1699, HFX_1700, HFX_1701 HFX_1702, HFX_1703, HFX_1704, HFX_1705, HFX_1706) and signalling and cellular processes were found (Tables S5 and S6). As expected, these results agree with previous studies showing the overexpression of these genes under nitrogen starvation in H. mediterranei (Esclapez et al. 2015). Gas vesicle formation significantly reduces the volume of the cytoplasm in cells by maintaining a large surface area of the cell for nutrient acquisition purposes (Hechler and Pfeifer 2013). Not surprisingly, the genes related to different CRISPR/Cas proteins (HFX_6314, HFX_6315, HFX_6316, HFX_6317, HFX_6318, HFX_6319, and HFX_6320) were overexpressed in response to the stress caused by the nitrogen starvation condition. Several studies have reported that the CRISPR/Cas system is activated under stress conditions as a prokaryotic defence system. Although details of the immune system activation remain unclear, alterations to the cell surface may prove to be an important mechanism (Sorek et al. 2013). Other genes related to stress processes, such as usp genes, displayed differences in their expression (Table S7). Usp is produced in response to deprivation of a wide range of nutrients (carbon, nitrogen, phosphate, sulphate and amino acids) (Nystrdm and Neidhardt 1992). In energy efficiency terms, metabolism generally slowed down under nitrogen starvation conditions (Table S8), as described in a previous study (Esclapez et al. 2015).

The Nsta $(\Delta g \ln A)$-Cx comparison showed 446 genes with differences in their expression patterns (Table 3). Some were involved mainly with nitrogen metabolism, transport systems and regulation processes (Tables S3, S4 and S9). Notably, nitrate assimilation genes (HFX_2002-2005, HFX_0844, HFX_0092 and HFX_0094) were overexpressed, while ammonium assimilation genes (HFX_1516, HFX_1518, HFX_2178) and denitrification genes (HFX_2183, HFX_2188, HFX_5091) were downregulated.

$g \ln A 2$ expression was also downregulated, and $g \ln A 3$ showed no differences in its expression, confirming that $g \ln A 2$ and $g \ln A 3$ did not replace $g \ln A$, which was proposed according to the above-cited results. The up- and downregulated genes related to the transport system were classified as transporters of ions, amino acids and sugars capable of acting as cellular signals. Most transcriptional regulators belonging to the arsR and $l r p$ families (HFX_1274, HFX_2192, HFX_2497, HFX_2520, HFX_4054 and HFX_4126) were downregulated in this comparison. Although the role of Lrp in response to environmental alterations is known in archaea, the role of ArsR remains unclear (Kyrpides and Ouzounis 1999; Napoli et al. 1999; Leonard et al. 2001; Peeters and Charlier 2010). Therefore, the transcriptional regulators of these families could be directly involved in the regulation of nitrogen metabolism in haloarchaea. Unexpectedly, the gas vesicle genes in the $\mathrm{Nsta}(\Delta g \ln A)$-Cx comparison showed no changes in their expression levels, and only the major gas vesicle protein GvpA (HFX_1696) was downregulated. Finally, the CRISPR/Cas system genes showed no changes in their expression levels (Fig. 7). Under the analysed conditions, HM26 could utilize high levels of energy to produce gas vesicles, while HM26- $\Delta \ln A$ could invest energy to alter the cell surface or to activate the immune system, using energy to maintain an efficient metabolism.

\section{Validation of the microarray results by RT-qPCR}

The representative genes ( $g \ln A 2$, gdh, nasD, nasA) involved in nitrogen metabolism, which showed changes in their expression profiles, were chosen for microarray data validation by RT-qPCR. The RT-qPCR results were consistent with the microarray expression data (Fig. 8) in the analysed genes. These analyses confirmed that the nas $A$ and

\begin{tabular}{|l|l|l|l|l|}
\hline Journal : Large 792 & Article No : 1169 & Pages : 14 & MS Code : EXT-19-Nov-0215 & Dispatch : 4-4-2020 \\
\hline
\end{tabular}




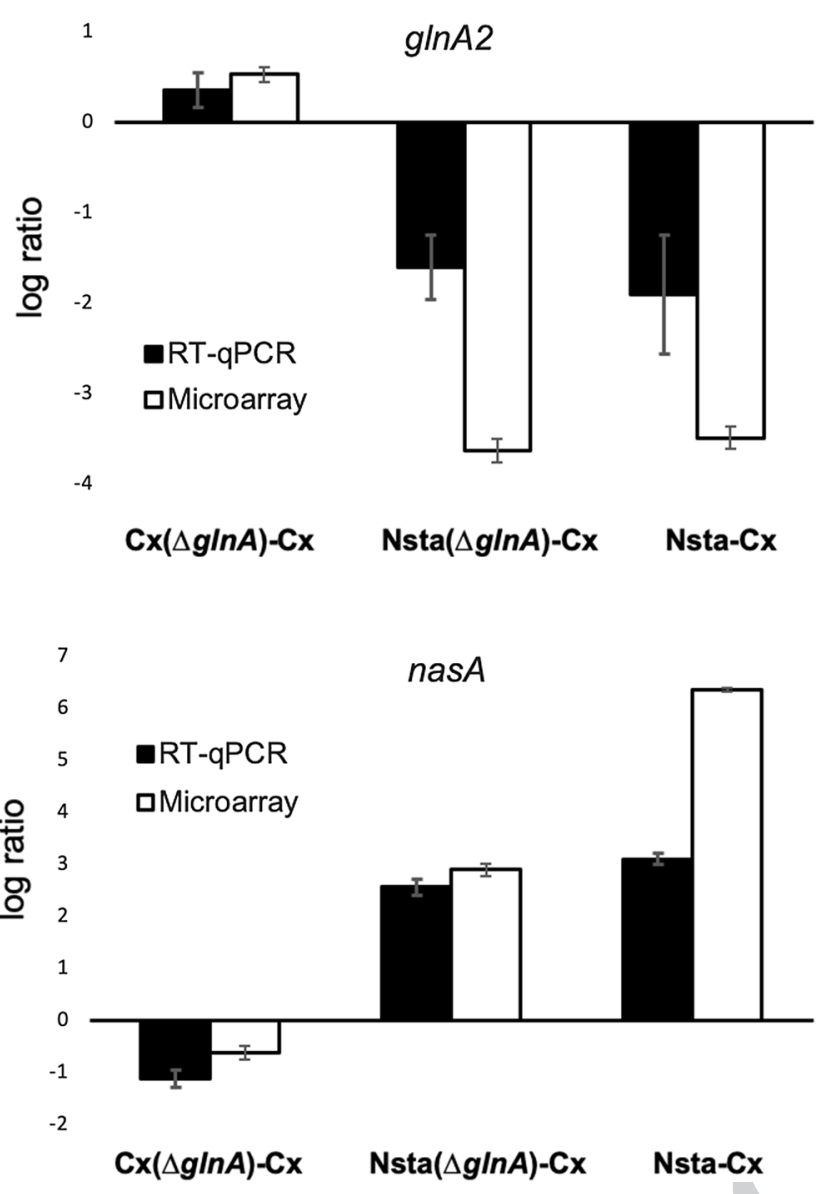

Fig. 8 Microarray data validation by RT-qPCR. The representative genes involved in nitrogen metabolism ( $\ln A 2$, gdh, nas $A$, nas $D)$ were quantified by RT-qPCR under three conditions: deletion mutant culture in complex medium supplemented with $40 \mathrm{mM}$ Gln in the mid-

$n a s D$ expression levels increased, whereas the $g \ln A 2$ and $g d h$ expression levels decreased in response to nitrogen starvation.

This work has demonstrated the essentiality of $g \ln A$ given the inability of the HM26- $\Delta g \ln A$ mutant to maintain the deletion under metabolically unfavourable conditions, such as the absence of glutamine. Under this condition, the gene conversion process occurred in the conditional deletion mutant (HM26- $\Delta g \ln A$ ), which favoured the increase in the number of parental chromosomes upon $g \ln A$ deletion. The $\operatorname{gln} A$ gene is expressed under nitrogen starvation conditions, while in both the mutant and parental strains in this condition, $g \ln A 2$ was downregulated, and $g \ln A 3$ did not show any difference. Therefore, $g \ln A 2$ and $g \ln A 3$ are not expressed under the same conditions as $g \ln A$. For this reason, $g \ln A 2$ and $g \ln A 3$ were unable to compensate for the lack of $g \ln A$.

Acknowledgements We thank Jörg Soppa for the useful comments on and assistance with this work. This work was funded by MICINN Grant Number BIO2013-42921P (to MJB), Generalitat Valenciana

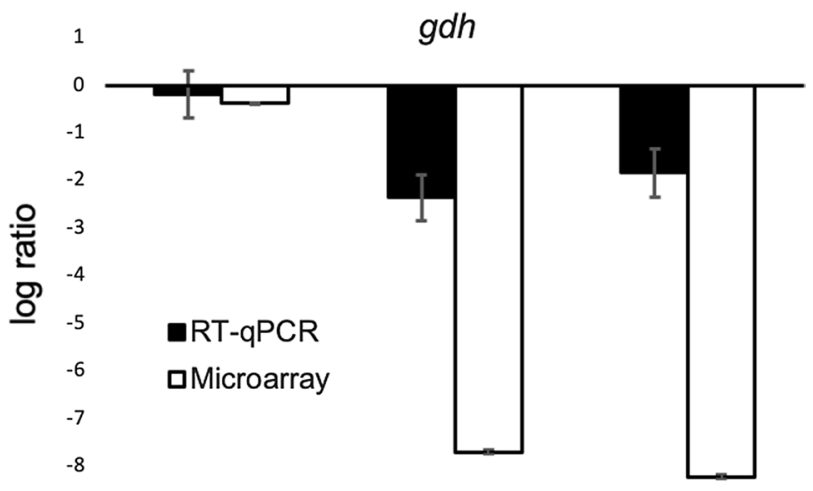

Cx( $(\Delta g \ln A)-C x \quad N s t a(\Delta g \ln A)-C x \quad$ Nsta-Cx

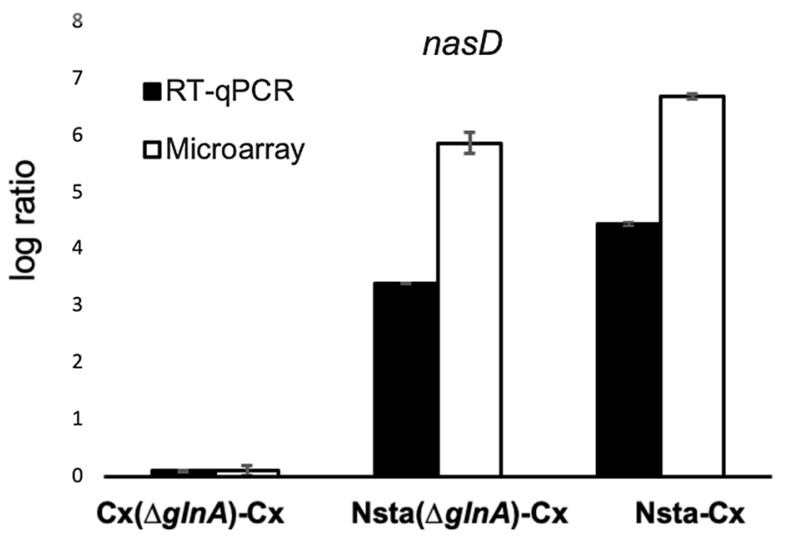

exponential growth phase $(\mathrm{Cx}(\Delta \mathrm{g} \ln \mathrm{A})-\mathrm{Cx})$, deletion mutant culture under nitrogen starvation $(\mathrm{Nsta}(\Delta g \ln A)-\mathrm{Cx})$, and parental strain culture under nitrogen starvation (Nsta-Cx). All the RT-qPCR results represent the average of triplicates ( \pm standard deviation)

Grant Number ACIF/2018/200 (to GP) and Universidad de Alicante (VIGROB-016).

Author contributions GP and VB designed and characterised the mutants; AV, JE, and MC prepared the array samples and performed the data collection; VHR, MCM and JE analysed the microarray data; GP and VHR wrote the paper; JE, VB, MC and MJB conducted the review and editing; MJB provided funding, project administration, and resources. All authors read and approved the final manuscript.

\section{Compliance with ethical standards}

Conflict of interest The authors declare that they have no conflict of interest.

\section{References}

Allers T, Ngo HP, Mevarech M, Lloyd RG (2004) Development of additional selectable markers for the halophilic archaeon Haloferax volcanii based on the leuB and trpA genes. Appl Environ Microbiol 70:943-953. https://doi.org/10.1128/aem.70.2.943-953.2004

\begin{tabular}{|l|l|l|l|l}
\hline Journal : Large 792 & Article No : 1169 & Pages : 14 & MS Code : EXT-19-Nov-0215 & Dispatch : 4-4-2020 \\
\hline
\end{tabular}


Berg IA, Kockelkorn D, Ramos-Vera WH, Say RF, Zarzycki J, Hügler M, Alber BE, Fuchs G (2010) Autotrophic carbon fixation in archaea. Nat Rev Microbiol 8:447-546. https://doi. org/10.1038/nrmicro2365

Bitan-Banin G, Ortenberg R, Mevarech M (2003) Development of a gene knockout system for the halophilic archaeon Haloferax volcanii by use of the pyrE gene. J Bacteriol 85:772-778. https ://doi.org/10.1128/aem.70.2.943-953.2004

Bonete MJ, Martínez-Espinosa RM, Pire C, Zafrilla B, Richardson DJ (2008) Nitrogen metabolism in haloarchaea. Saline Syst 4:9. https://doi.org/10.1186/1746-1448-4-9

Brown JR, Masuchi Y, Robb FT, Doolittle WF (1994) Evolutionary relationships of bacterial and archaeal glutamine synthetase genes. J Mol Evol 38:566-576. https://doi.org/10.1007/bf001 75876

Chant J, Hui I, De Jong-Wong D, Shimmin L, Dennis PP (1986) The protein synthesizing machinery of the Archaebacterium Halobacterium cutirubrum: molecular characterization. Sys Appl Microbiol 7(1):106-114. https://doi.org/10.1016/S0723 -2020(86)80132-1

Chavez S, Lucena JM, Reyes JC, Florencio FJ, Candau P (1999) The presence of glutamate dehydrogenase is a selective advantage for the cyanobacterium Synechocystis sp. strain PCC 6803 under nonexponential growth conditions. J Bacteriol 181(3):808-813

Cline SW, Lam WL, Charlebois RL, Schalkwyk LC, Doolittle WF (1989) Transformation methods for halophilic archaebacteria. Can J Microbiol 35(1):148-152. https://doi.org/10.1139/ m89-022

Cohen-Kupiec R, Marx CJ, Leigh JA (1999) Function and regulation of glnA in the methanogenic archaeon Methanococcus maripaludis. J Bacteriol 181(1):56-261

Cupp JR, McAlister-Henn L (1993) Kinetic analysis of NAD+-isocitrate dehydrogenase with altered isocitrate binding sites: contribution of IDH1 and IDH2 subunits to regulation and catalysis. Biochemistry 32(36):9323-9328. https://doi.org/10.1021/bi000 $87 \mathrm{a} 010$

Domínguez-Martín MA, Díez J, García-Fernández JM (2016) Physiological studies of glutamine synthetases I and III from Synechococcus $\mathrm{sp}$. WH7803 reveal differential regulation. Front Microbiol 7:969. https://doi.org/10.3389/fmicb.2016.00969

Eisenberg D, Gill HS, Pfluegl GMU, Rotstein SH (2000) Structurefunction relationships of glutamine synthetases. Biochim Biophys Acta 1477(1-2):122-145. https://doi.org/10.1016/s0167 $-4838(99) 00270-8$

Esclapez J, Pire C, Camacho M, Bautista V, Martínez-Espinosa RM, Zafrilla B, Vegara A, Alcaraz LA, Bonete MJ (2015) Transcriptional profiles of Haloferax mediterranei based on nitrogen availability. J Biotechnol 193:100-107. https://doi.org/10.1016/j.jbiot ec.2014.11.018

Fernandez R, Rodriguez F, Gonzalez J, Ruiz F (1986) Accumulation of poly(beta-hydroxybutyrate) by Halobacteria. Appl Environ Microbiol 51:214-216

Fisher SH (1989) Glutamate synthesis in Streptomyces coelicolor. J Bacteriol 171(5):2372-2377. https://doi.org/10.1128/ jb.171.5.2372-2377.1989

Han J, Hou J, Zhang F, AiG LiM, Cai S, Liu H, Wang L, Wang Z, Zhang S, Cai L, Zhao D, Zhou J, Xiang H (2013) Multiple propionyl coenzyme A-supplying pathways for production of the bioplastic poly(3-hydroxybutyrate-co-3-hydroxyvalerate) in Haloferax mediterranei. Appl Environ Microbiol 79(9):2922-2931. https ://doi.org/10.1128/aem.03915-12

Harth G, Maslesa-Galic S, Tullius MV, Horwitz MA (2005) All four Mycobacterium tuberculosis glnA genes encode glutamine synthetase activities but only GlnA1 is abundantly expressed and essential for bacterial homeostasis. Mol Microbiol 58(4):11571172. https://doi.org/10.1111/j.1365-2958.2005.04899.x
Hechler T, Pfeifer F (2013) Anaerobiosis inhibits gas vesicle formation in halophilic Archaea. Mol Microbiol 71(1):132-145. https://doi. org/10.1111/j.1365-2958.2008.06517.x

Herrmann U, Soppa J (2002) Cell cycle-dependent expression of an essential SMC-like protein and dynamic chromosome localization in the archaeon Halobacterium salinarum. Mol Microbiol 46(2):395-409. https://doi.org/10.1046/j.1365-2958.2002.03181.x

Hildenbrand C, Stock T, Lange C, Rother M, Soppa J (2011) Genome copy numbers and gene conversion in methanogenic archaea. J Bacteriol 193(3):734-743. https://doi.org/10.1128/jb.01016-10

Jantzer K, Zerulla K, Soppa J (2011) Phenotyping in the archaea: optimization of growth parameters and analysis of mutants of Haloferax volcanii. FEMS Microbiol Lett 322(2):123-130. https://doi. org/10.1111/j.1574-6968.2011.02341.x

Kappler U, Histon WM, McEwan AG (2002) Control of dimethylsulfoxide reductase expression in Rhodobacter capsulatus: the role of carbon metabolites and the response regulators DorR and RegA. Microbiology 148(Pt 2):605-614. https://doi.org/10.1099/00221 287-148-2-605

Kim JN, Méndez-García C, Geier RR, Iakiviak M, Chang J, Cann I, Mackie RI (2017) Metabolic networks for nitrogen utilization in Prevotella ruminicola23. Sci Rep 7:7851. https://doi. org/10.1038/2Fs41598-017-08463-3

Kyrpides NC, Ouzounis CA (1999) Transcription in archaea. Proc Natl Acad Sci USA 96(15):8545-8550. https://doi.org/10.1073/ pnas.96.15.8545

Lange C, Zerrulla K, Breuert S, Soppa J (2011) Gene conversion results in the equalization of genome copies in the polyploid haloarchaeon Haloferax volcanii. Mol Microbiol 80(3):666-677. https ://doi.org/10.1111/j.1365-2958.2011.07600.x

Leonard PM, Smits SH, Sedelnikova SE, Brinkman AB, de Vos WM, Van der Oos J, Rice DW, Rafferty JB (2001) Crystal structure ofthe Lrp-like transcriptional regulator from the archaeon Pyrococcus furiosus. EMBO J 20(5):990-997. https://doi.org/10.1093/ emboj/20.5.990

Li X, Liu T, Wu Y, Zhao G, Zhou Z (2010) Derepressive effect of $\mathrm{NH} 4+$ on hydrogen production by deleting the glnA1 gene in Rhodobacter sphaeroides. Biotechnol Bioeng 106(4):564-572. https://doi.org/10.1002/bit.22722

Mackwan RR, Carver GT, Drake JW, Grogan DW (2007) An unusual pattern of spontaneous mutations recovered in the halophilic archaeon Haloferax volcanii. Genetics 176(1):697-702. https:// doi.org/10.1534/genetics.106.069666

Muro-Pastor MI, Reyes JC, Florencio FJ (2005) Ammonium assimilation in cyanobacteria. Photosynth Res 83(2):135-150. https://doi. org/10.1007/s11120-004-2082-7

Napoli A, Van der Oost J, Sensen CW, Charlebois RL, Rossi M, Ciaramella M (1999) An Lrp-like protein of the hyperthermophilic archaeon Sulfolobus solfataricus which binds to its own promoter. J Bacteriol 181(5):1474-1480

Nystrdm T, Neidhardt FC (1992) Cloning, mapping and nucleotide sequencing of a gene encoding a universal stress protein in Escherichia coli. Mol Microbiol 6(21):3187-3198. https://doi. org/10.1111/j.1365-2958.1992.tb01774.x

Pedro-Roig L, Camacho M, Bonete MJ (2011) In vitro proof of direct regulation of glutamine synthetase by GlnK proteins in the extreme halophilic archaeon Haloferax mediterranei. Biochem Soc Trans 39(1):259-262. https://doi.org/10.1042/bst0390259

Pedro-Roig L, Camacho M (1834) Bonete MJ (2013) Regulation of ammonium assimilation in Haloferax mediterranei: interaction between glutamine synthetase and two GlnK proteins. Biochim Biophys Acta 1:16-23. https://doi.org/10.1016/j.bbapa p.2012.10.006

Pedro-Roig L, Lange C, Bonete MJ, Soppa J, Maupin-Furlow J (2013) Nitrogen regulation of protein-protein interactions and transcript levels of GlnK PII regulator and AmtB ammonium transporter

\begin{tabular}{|l|l|l|l|l|}
\hline Journal : Large 792 & Article No : 1169 & Pages : 14 & MS Code : EXT-19-Nov-0215 & Dispatch : 4-4-2020 \\
\hline
\end{tabular}


homologs in Archaea. MicrobiologyOpen 2(5):826-840. https:// doi.org/10.1002/mbo3.120

Peeters E, Charlier D (2010) The Lrp family of transcription regulators in Archaea. Archaea. https://doi.org/10.1155/2010/750457

Pire C, Martínez-Espinosa RM, Pérez-Pomares F, Esclapez J, Bonete MJ (2014) Ferredoxin-dependent glutamate synthase: involvement in ammonium assimilation in Haloferax mediterranei. Extremophiles 18(1):147-159. https://doi.org/10.1007/s00792-013-0606-9

Reitzer L (2003) Nitrogen assimilation and global regulation in Escherichia coli. Annu Rev Microbiol 57:155-176. https://doi. org/10.1146/annurev.micro.57.030502.090820

Reyes JC, Florencio F (1994) A mutant lacking the glutamine synthetase gene $(\operatorname{gn} \mathrm{ln})$ is impaired in the regulation of the nitrate assimilation system in the cyanobacterium Synechocystis sp. strain PCC 6803. J Bacteriol 176(24):7516-7523. https://doi. org/10.1128/jb.176.24.7516-7523.1994

Rodríguez-Valera F, Ruiz-Berraquero F, Ramos-Cormezana A (1980) Behaviour of mixed populations of halophilic bacteria in continuous cultures. Can J Microbiol 26(11):1259-1263. https://doi. org $/ 10.1139 / \mathrm{m} 80-210$

Soppa J (2011) Ploidy and gene conversion in Archaea. Biochem Soc Trans 39(1):150-154. https://doi.org/10.1042/bst0390150

Soppa J (2013) Evolutionary advantages of polyploidy in halophilic archaea. Biochem Soc Trans 41(1):339-343. https://doi. org/10.1042/bst20120315

Sorek R, Lawrence CM, Wiedenheft B (2013) CRISPR-mediated adaptive immune systems in Bacteria and Archaea. Annu Rev Biochem 82:237-266. https://doi.org/10.1146/annurev-bioch em-072911-172315

Todd JD, Curson AR, Nikolaidou-Katsaraidou N, Brearley CA, Watmough NJ, Chan Y, Page PC, Sun L, Johnston AW (2010) Molecular dissection of bacterial acrylate catabolism: unexpected links with dimethylsulfoniopropionate catabolism and dimethyl sulfide production. Environ Microbiol 12(2):327-343. https://doi.org/10. 1111/j.1462-2920.2009.02071.x
Tomita T, Miyazaki T, Miyazaki J, Kuzuyama T, Nishiyama M (2010) Hetero-oligomeric glutamate dehydrogenase from Thermus thermophilus. Microbiology 156(12):3801-3813. https://doi. org/10.1099/mic.0.042721-0

van Heeswijk WC, Westerhoff HV, Boogerd FC (2013) Nitrogen assimilation in Escherichia coli: putting molecular data into a systems perspective. Microbiol Mol Biol Rev 77(4):628-695. https://doi. org/10.1128/MMBR.00025-13

Van-Thuoc D, Huu-Phong T, Thi-Binh N, Thi-Tho N, Minh-Lam D, Quillaguamán J (2012) Polyester production by halophilic and halotolerant bacterial strains obtained from mangrove soil samples located in Northern Vietnam. MicrobiologyOpen 1(4):395-406. https://doi.org/10.1002/mbo3.44

Vegara A (2017) Glutamina sintetasas recombinantes de Haloferax mediterranei. Dissertation, University of Alicante (Spain)

Woods DR, Reid SJ (1993) Recent developments on the regulation and structure of glutamine synthetase enzymes from selected bacterial groups. FEMS Microbiol Rev 11(4):273-284. https://doi. org/10.1111/j.1574-6976.1993.tb00001.x

Zerulla K, Chimileski S, Näther D, Gophna U, Papke RT, Soppa J (2014) DNA as a phosphate storage polymer and the alternative advantages of polyploidy for growth or survival. PLoS ONE 9(4):e94819. https://doi.org/10.1371/journal.pone.0094819

Zerulla K, Soppa J (2014) Polyploidy in haloarchaea: advantages for growth and survival. Front Microbiol 274(5):1-8. https://doi. org/10.3389/fmicb.2014.00274

Publisher's Note Springer Nature remains neutral with regard to jurisdictional claims in published maps and institutional affiliations.

\begin{tabular}{|l|l|l|l|l|}
\hline Journal : Large 792 & Article No : 1169 & Pages : 14 & MS Code : EXT-19-Nov-0215 & Dispatch : 4-4-2020 \\
\hline
\end{tabular}


Journal: $\quad \mathbf{7 9 2}$

Article: 1169

\section{Author Query Form}

Please ensure you fill out your response to the queries raised below and return this form along with your corrections

Dear Author

During the process of typesetting your article, the following queries have arisen. Please check your typeset proof carefully against the queries listed below and mark the necessary changes either directly on the proof/online grid or in the 'Author's response' area provided below

\begin{tabular}{|l|l|c|}
\hline Query & Details Required & Author's Response \\
\hline AQ1 & $\begin{array}{l}\text { Figure: Figure [6] was received; however, no citation was provided in the manuscript. } \\
\text { Please check and confirm the inserted citation of Figure is correct. If not, please } \\
\text { suggest an alternative citation. Please note that figures should be cited in ascending } \\
\text { numerical order in the text and should be inside the main body of the text. }\end{array}$ & \\
\hline
\end{tabular}

